\title{
Penerapan Algoritma C 4.5 Pada Pengaruh Iklan Online Terhadap Minat Beli Konsumen di Masa Pandemic Covid-19
}

\author{
Zelvi Gustiana ${ }^{1}$, Welnof Satria ${ }^{2}$, Jhon Simon ${ }^{3}$ \\ 1,2, Teknologi Informasi, Universitas Dharmawangsa \\ ${ }^{3}$ Administrasi Publik, Universitas Dharmawangsa
}

\begin{tabular}{|c|c|}
\hline Article Info & ABSTRAK \\
\hline $\begin{array}{l}\text { Article History: } \\
\text { Received Jun } 12^{\text {th }}, 2021 \\
\text { Revised Aug } 20^{\text {th }}, 2021 \\
\text { Accepted Aug } 31^{\text {th }}, 2021\end{array}$ & $\begin{array}{l}\text { Seiring berkembangnya teknologi, semua orang dapat dimudahkan } \\
\text { pekerjaannya. Salah satunya adalah promosi terhadap produk yang dijual. } \\
\text { Kini maraksekali promosi yang dilakukan secara online melalui media sosial, } \text {, }{ }_{\text {a }} \text { terlebih pada masa pandemic Covid-19. Tidak bolehnya sosialisasi secara } \\
\text { langsung menyebabkan banyak orang-orang yang lebih tertarik berbelanja } \\
\text { secara online di media sosial mereka. Tapi terjadi fenomena dimana }\end{array}$ \\
\hline $\begin{array}{l}\text { Kata Kunci: } \\
\text { Algoritma C } 4.5 \\
\text { Data Mining } \\
\text { Harga Iklan } \\
\text { PromosiProduk }\end{array}$ & $\begin{array}{l}\text { kebanyakan produk yang dipromosikan tidak mencantumkan harga pada } \\
\text { iklan. Ini menarik perhatian peneliti untuk melakukan pengamatan dan } \\
\text { penelitian terhadap iklan produk yang tidak mencantumkan label harga } \\
\text { apakah masih menarik orang-orang untuk membeli dengan menggunakan } \\
\text { metode Algoritma C 4.5. Algoritma C } 4.5 \text { merupakan salah satu bagian dari } \\
\text { Data Mining klasifikasi. Atribut yang menjadi acuan adalah jenis kelamin, } \\
\text { Attention, Interest, Search serta Action. Hasil dari penelitian menunjukkan } \\
\text { bahwa atribut Attention memiliki Gain tertinggi yang menjadiakar dari pohon } \\
\text { keputusan. }\end{array}$ \\
\hline
\end{tabular}

\author{
Corresponding Author: *First Author \\ Nama : Zelvi Gustiana \\ Program Studi : Teknologi Informasi \\ Afiliasi : Universitas Dharmawangsa \\ Email: zelvi@dharmawangsa.ac.id
}

\section{PENDAHULUAN}

Promosi merupakan bagian yang sangat mempengaruhi dalam salah satu usaha dan bisnis, apalagi hal tersebut berhubungan langsung dengan market yang terus bergerak(1). Pada zaman kemajuan teknologi yang terus berkembang pada saat ini, promosi dilakukan dengan berbagai cara untuk mendapatkan keuntungan tinggi pada usaha atau bisnis yang dimiliki oleh masyarakat(2). Kemudian promosi juga merupakan salah satu upaya yang digunakan untuk memberitahukan atau menawarkan produk atau jasa kepada calon konsumen untuk melakukan pembelian produk tersebut(3). Promosi juga bertujuan untuk menciptakan loyalitas merek sebuah produk dengan cara meningkatkan kesadaran pelanggan terhadap produk tersebut(4).

Sekarang ini kemajuan teknologi di bidang sosial media membuat masyarakat ikut memanfaatnya salah satunya dengan cara melakukan aktivitas jual beli disana. Media promosi secara online menjadi salah satu peluang yang sangat mumpuni karena banyak sekali orang-orang yang memakai media sosial pada saat ini. Salah satu media sosial yang banyak digunakan oleh masyarakat Indonesia adalah Instagram. Menurut data yang telah dirilis oleh Napoleon Cat, pada periode Januari-Mei 2020, pengguna platform intagram yang ada di Indonesia mencapai 69,2 juta pengguna. Dilihat dari itu, terdapat peluang besaar yang bisa dimanfaatkan pelaku usaha untuk mempromosikan produknya dengan memasang iklan di Instagram. Biasanya orang-orang beriklan di Instagram menggunakan foto, iklan dengan video, iklan story dan iklan carousel. Dalam semua penyajian yang berbeda itu, salah satu Teknik iklan yang menjadi perhatian adalah iklan produk di Instagram tidak 
mencantumkan harga atau informasi harga produk secara detail, sehingga konsumen harus menghubungi custumer service ataupun penjualnya secara langsung untuk menanyakan harga(5). Biasanya produk yang diperjual-belikan seperti itu biasanya produk yang susah didapatkan dipasaran umum, sehingga pembeli masih banyak menerka harga dari produk yang mereka taksir dari iklan(6).Oleh karena peneliti tertarik untuk melihat ketertarikan masyarakat apakah akan membeli produk yang di promosikan melalui iklan di media sosial Instagram terutama pada masa Pandemi Covid-19 saat ini dengan menggunakan Data mining klasifikasi yaitu Algoritma C 4.5(7).

Penelitian terdahulu yang berkaitan dengan penelitian ini adalah Analisis dan Penerapan Algorithma C 4.5 Dalam Data Mining Untuk Menunjang Strategi Promosi Prodi Informatika UPGRIS yang memiliki hasil akurasi sebesar $89.33 \%$ (Good Classification) dari pemodelan(8). Kemudian penelitian Prediksi Promosi Jabatan Karyawan Dengan Algoritma C 4.5 (Studi Kasus : Apartemen Senayan Jakarta) yang memiliki hasil aturan dari klasifikasi yang karyawan dipromosikan dan yang tidak dipromosikan dengan akurasi 78.00\%(9). Kemudian tentang teori AISAS yaitu lima dimensi Attention, Interest, Search, Action, dan Share. Pada teori ini membuat calon pembeli sadar akan produk, kemudian tertarik dan sampai ke membeli barang dan memberikan ulasan tentang produk. Kemudian iklan yang berada di Instagram yang biasa dikenal dengan Instagram Ads merupakan salah satu media promosi yang banyak diminati pelaku usaha. Instagram Ads merupakan salah satu kegiatan pemasangan iklan melalui media Instagram yan menjangkau target konsumen yang lebih luas. Layanan Instagram membantu pelaku usaha mempromosikan produknya.

\section{METODE PENELITIAN}

Metode yang penulis gunakan dalam penelitian ini merupakan metode terapan yang menggunakan CRISP-DM (Cross-Industry Standard Process for Data Mining) dimana metode ini menerapkan proses standar data mining yang diaplikasikan oleh berbagai sector industri. Adapun Langkah-langkahnya adalah sebagai berikut :

a. Business Understanding

Penelitian ini memiliki tujuan untuk mengetahui apakah iklan yang dipasang pada media sosial mempengaruhi pola pembelian produk oleh konsumen terutama dalam masa pandemi Covid-19 ini. Oleh karena itu, pada penelitian ini yang menjadi sasaran adalah para pengguna Instagram yang aktif.

b. Data Understanding

Pada tahap ini digunakan metode survey dimana bertujuan untuk mengumpulkan informasi mengenai variabel dan responden yang dianggap sebagai objek populasi dengan menggunakan kuesioner yang telah dibuat. Populasi dala penelitian ini bersifat anonim, tetapi ditujukan untuk para pengguna Instagram aktif. Penelitian ini menggunakan responden berdasarkan pada jenis kelamin yang digunakan sebagai sampel. Teknik pengambilan sampel yang digunakan pada penelitian ini adalah purposive sampling yaitu dengan menetapkan responden untuk dijadukan sampel berdasarkan kriteria. Kriteria responden yang dimaksudkan dalam penelitian ini adalah mereka yang menggunakan Instagram secara aktif dan berdasarkan jenis kelamin responden. Jumlah sampel yang diambil adalah 30 dari 200 data responden. Dan digunakan beberapa indikator pada kuisioner untuk mengukur tingkat efektivitas iklan pada media sosial.

c. Data Preparation

Setelah data didapatkan oleh peneliti, Langkah yang dilakukan selanjutnya adalah mempersiapkan data tersebut sebelum melakukan pemodelan dengan data mining. Penyiapan data pada penelitian ini adalah dengan menentukan nilai-nilai yang didapatkan dari hasil kuesioner ke dalam variabel-variabel yang ada di dalam penelitian. Yang mana variabel yang digunakan tersebut adalah Attention (perhatian), Interest (Ketertarikan), Search (Pencarian) dan Action (Aksi membeli). Variabel Attention diperlukan untuk mengukur seberapa sering pengguna Instagram melihat iklan yang ada di beranda Instagram mereka. Variabel Interest figunakan utnuk mengukur seberapa sering pengguna Instagram membaca caption atau informasi mengenai promosi pada iklan produk tersebut. Variabel search digunakan untuk mengukur seberapa sering pengguna Instagram dalam mencari informasi lebih lanjut bahkan mencari kontak untuk mencari informasi tentang produk yang diiklankan. Dan variabel action merupakan bentuk pengukuran seberapa sering pengguna Instagram dalam melakukan aksi yaitu membeli produk dari iklan tersebut.

d. Modelling 
Tahap selanjutnya adalah menentukan algoritma yaitu dengan tahap modelling. Pada tahap ini terjadi penggambaran terhadap aturan-aturan bagaimana pila pembelian yang dilakukan oleh pembelian yang dilakukan oleh konsumen yang dipengaruhi oleh tayangan iklan yang ada di Instagram. Dari model ini akan terlihat terlihat variabel-variabel apa saja yang berpengaruh terhadap Tindakan pembelian produk yang ada di Instagram, sehingga hal tersebut dapat dijadikan kesimpulan apakah penggunaan iklan tersebut dapat dinilai efektif untuk digunakan oleh para pengiklan atau penjual.

e. Evaluation

Tahap ini merupakan penerapan pengujian yang menggunakan cross validation pada model yang digunakan untuk mendapatkan confusion matrix dan ROC curve sehingga dapat diketahui tingkat akurasi dari rule yang terbentuk. Confusion matrix dapat digunakan untuk mendapatkan untuk menggambarkan seberapa baik sebuah klasifikasi dilakukan. Sedangkan ROC curve merupakan sebauh penggambaran tentang pemisahan antar class yang berbeda. Dalam penelitian ini terdapat class "Membeli" yang memiliki arti melakukan pembelian dan class "Tidak" yang tidak melakukan pembelian. Tahapannya secara singkat dapat dilihat pada Gambar 1 di bawah ini :

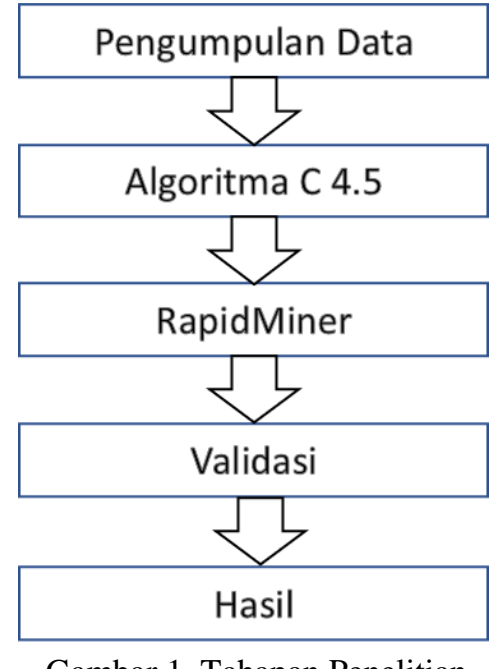

Gambar 1. Tahapan Penelitian

\section{ANALISA DAN HASIL}

Berikut ini adalah analisa dan hasil dari penelitian mengenai penerapan Algoritma C 4.5 pada Pengaruh Iklan Online Terhadap Minat Beli Konsumen di Masa Pandemid Covid-19.

\subsection{Business Understanding}

Iklan yang dipasang pada media sosial merupakan salah satu bagian dari strategi pemasaran yang lumayan efektif karena para pengguna media sosial saat ini sangat banyak. Salah satu contoh media sosial yang banyak peminatnya adalah Instagram, khususnya sangat banyak digunakan oleh masyarakat Indonesia. Apalagi saat masa pandemic Covid-19 ini, para pengguna media sosial menjadi lebih aktif karena banyaknya waktu luang. Para pengiklan yang mengunggah iklan produknya dalam berbagai jenis seperti gambar, video ataupun gabungan keduanya. Biasanya pengiklan membuat desain iklan yang unik dan menarik untuk menarik minat pembeli mereka. Tapi diantara semua model pengiklanan ada salah satu model iklan yang hanya menampilkan bentuk dan detail produk tanpa adanya harga produk. Diharapkan penelitian ini dapat memberikan manfaat bagi pengiklan apakah membuat iklan tanpa harga dapat menjadi pilihan dalam mengiklankan produknya dengan cara memperlihatkan pola pembelian konsumen yang telah diteliti.

\subsection{Data Understanding}

Penelitian ini menggunakan kuesioner yang disebarkan kepada para pengguna media sosial. Terdapat 250 data responden. Berikut ini adalah betuk atribut yang ada pada kuesioner.

Tabel 1. Atribut Kuesioner

\begin{tabular}{|l|l|l|}
\hline No & \multicolumn{1}{|c|}{ Atribut } & \multicolumn{1}{c|}{ Keterangan } \\
\hline 1 & Jenis Kelamin Responden & Laki-laki / Perempuan \\
\hline 2 & Attention (Perhatian) & $\begin{array}{l}\text { Tidak pernah, Jarang, Kadang-kadang, sering, } \\
\text { sangat sering }\end{array}$ \\
\hline
\end{tabular}




\begin{tabular}{|l|l|l|}
\hline 3 & Interest (Ketertarikan) & $\begin{array}{l}\text { Tidak pernah, Jarang, Kadang-kadang, sering, } \\
\text { sangat sering }\end{array}$ \\
\hline 4 & Search & $\begin{array}{l}\text { Tidak pernah, Jarang, Kadang-kadang, sering, } \\
\text { sangat sering }\end{array}$ \\
\hline 5 & Action (Pembelian) & Membeli atau Tidak \\
\hline
\end{tabular}

\subsection{Data Preparation}

Data yang telah dikumpulkan akan diolah terlebih dahulu dengan melakukan terjemah data dengan skala interval menjadi data ordinal Kembali, sehingga data sudah siap untuk dimodelkan. Data yang sudah siap untuk diolah adalah sebagai berikut.

Tabel 2. Atribut Kuesioner

\begin{tabular}{|c|c|c|c|c|c|}
\hline No & Jenis Kelamin & Attention & Interest & Search & Action \\
\hline 1 & Perempuan & Sering & Sangat Sering & Jarang & Membeli \\
\hline 2 & Laki-Laki & Kadang-Kadang & Jarang & Jarang & Tidak \\
\hline 3 & Laki-Laki & Kadang-Kadang & Sering & Jarang & Membeli \\
\hline 4 & Perempuan & Sering & Sering & Sangat Sering & Tidak \\
\hline 5 & Perempuan & Sering & Sering & Sangat Sering & Tidak \\
\hline 6 & Perempuan & Sangat Sering & Kadang-kadang & Jarang & Membeli \\
\hline$\ldots$ & .... & .... & .... & .... & $\ldots$ \\
\hline 250 & Laki-Laki & Kadang-Kadang & Sering & Sering & Membeli \\
\hline
\end{tabular}

\subsection{Modelling}

a) Pemodelan dengan Cross Validation

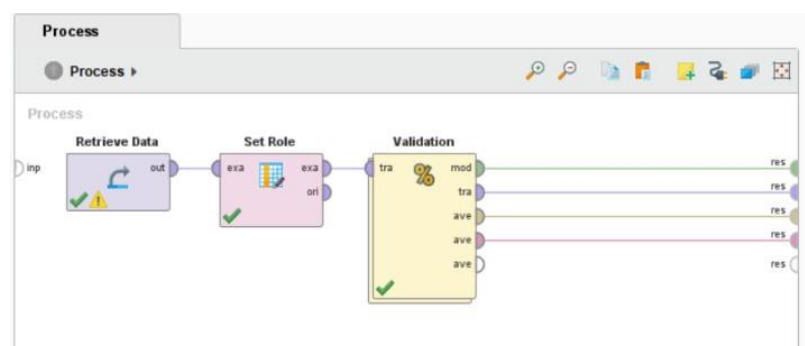

Gambar 2. Tahapan Modeling dengan Cross Validation

Pada tahap ini terjadi pengambilan data yang ada pada Excel yang kemudian dipersiapkan untuk ke tahap berikutnya yang berada pada tahap Algoritma C 4.5

b) Pemodelan dengan menggunakan Algoritma C 4.5

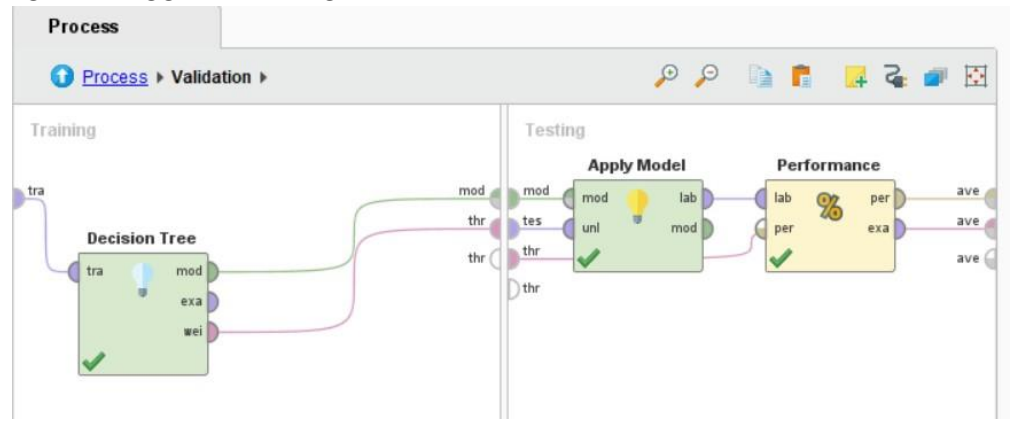

Gambar 3. Tahapan Modeling menggunakan Algoritma C 4.5 
c) Pohon Keputusan

Tabel 3. Nilai Entropy dan Gain

\begin{tabular}{|c|c|c|c|c|c|}
\hline \multirow{2}{*}{ Atribut } & Jumlah & Ya & Tidak & Entropy & Gain \\
\cline { 2 - 6 } & 30 & 17 & 13 & $\mathbf{0 , 9 9 2}$ & \\
\hline Jenis Kelamin & & & & & 0,024433467 \\
\hline Perempuan & 17 & 11 & 6 & 0,942168 & \\
\hline Laki-laki & 13 & 6 & 7 & 1,00078 & \\
\hline Attention & & & & & $\mathbf{0 , 5 5 2 2 3 5 8 6 7}$ \\
\hline Tidak Pernah & 1 & 0 & 1 & 0 & \\
\hline Jarang & 3 & 0 & 3 & 0 & \\
\hline Kadang-Kadang & 8 & 1 & 7 & 0,54356 & \\
\hline Sering & 12 & 11 & 1 & 0,413977 & \\
\hline Sangat Sering & 6 & 5 & 1 & 0,64612 & \\
\hline Interest & & & & & 0,366755333 \\
\hline Tidak Pernah & 1 & 0 & 1 & 0 & \\
\hline Jarang & 6 & 0 & 6 & 0 & \\
\hline Kadang-Kadang & 3 & 2 & 1 & 0,9234 & \\
\hline Sering & 14 & 10 & 4 & 0,86503 & \\
\hline Sangat Sering & 6 & 5 & 1 & 0,64612 & \\
\hline Search & & & & & 0,550651 \\
\hline Tidak Pernah & 9 & 0 & 9 & 0 & \\
\hline Jarang & 11 & 8 & 3 & 0,85125 & \\
\hline Kadang-Kadang & 4 & 4 & 0 & 0 & \\
\hline Sering & 0 & 0 & 0 & 0 & \\
\hline Sangat Sering & 6 & 5 & 1 & 0,64612 & \\
\hline
\end{tabular}

Pada tabel di atas ditunjukkan bahwa atribut yang memiliki Gain tertinggi adalah Atribut Attention sehingga Attention akan menjadi akar pada pohon keputusan.

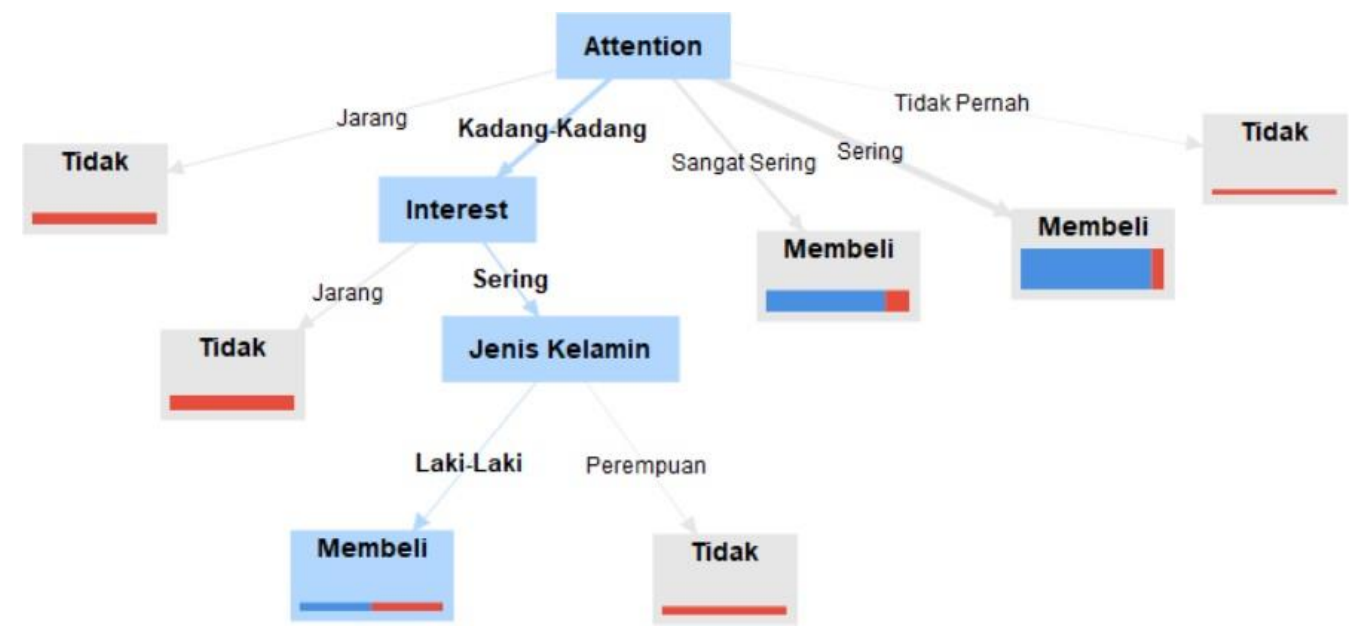

Gambar 4. Pohon Keputusan

\subsection{Evaluation}

Untuk evaluasi pada model ini, akan dilakukan eksekusi dengan software Rapidminer, yaitu untuk melihat tingkat akurasi terhadap proses yang dilakukan. 


\begin{tabular}{|c|c|c|c|}
\hline & true Membeli & true Tidak & class precision \\
\hline pred. Membeli & 5 & 0 & $100.00 \%$ \\
\hline pred. Tidak & 0 & 4 & $100.00 \%$ \\
\hline class recall & $100.00 \%$ & $100.00 \%$ & \\
\hline
\end{tabular}

Gambar 5. Akurasi pada Confussion Matrix

\section{KESIMPULAN}

Dari pembahasan yang telah dilakukan dapat disimpulkan iklan online sangat berpengaruh kepada pola pembelian konsumen, dimana atribut yang menjadi akar adalah Attention (Perhatian). Dengan demikian untuk penjual atau pemakai iklan online harus mampu menarik perhatian calon pembeli mereka agar calon pembeli mereka sampai ke tahap Action (aksi membeli). Pengiklan harus mencantumkan informasi kontak dan caption iklan yang digunakan untuk menarik perhatian calon pembeli. Efektivitas dari model yang didadapatkan adalah $100 \%$ yang di coba pada Confussion Matrix, artinya klasifikasi yang dilakukan masuk ke dalam kelompok Good Classification

\section{REFERENSI}

[1] Puguh Kurniawan, Puspitarini DS, Nuraeni R, Fadli R, Indika DR, Jovita C, et al. Pemanfaatan Media Sosial Instagram Akun@Vapormxpku Dalam Meningkatkan Promosi Penjualan. J Bisnis Terap [Internet]. 2019;3(9):2532. Available from: http://journal.trunojoyo.ac.id/kompetensi/article/view/3533

[2] Faisal IA, Rohmiyati Y. Analisis Pemanfaatan Media Instagram Sebagai Promosi Perpustakaan Provinsi Jawa Tengah. J Ilmu Perpust [Internet]. 2017;6(4):281-90. Available from: https://ejournal3.undip.ac.id/index.php/jip/article/view/23234

[3] Tahun N, Algoritma P, Sistem CD, Kasus S, Kabupaten DI. Penerapan algoritma c 4.5 dalam sistem pendukung keputusan evaluasi kinerja fasilitator pamsimas (studi kasus di kabupaten kampar). 2020;1(1):20-8.

[4] Hasmin E, Aisa S. Penerapan Algoritma C4.5 Untuk Penentuan Penerima Beasiswa Mahasiswa. CogITo Smart J. 2019;5(2):308.

[5] Rachmawati F. Analisis Algoritma C4 . 5 Untuk Pengangkatan Karyawan : Fitria Rachmawati. 2016;6(2):25-36.

[6] Azwanti N. Analisa Algoritma C4.5 Untuk Memprediksi Penjualan Motor Pada Pt. Capella Dinamik Nusantara Cabang Muka Kuning. Inform Mulawarman J Ilm Ilmu Komput. 2018;13(1):33.

[7] Sandrawira Anggraini, Sarjon Defit GWN. Analisis Data Mining Penjualan Ban Menggunakan. J Ilmu Tek Elektro Komput dan Inform. 2018;4(2):136-43.

[8] Words K. 伴征 1 ·矢島啓 2 - 泉谷 隆志 3. 2018;74(5):523-8.

[9] Sunarti S. Prediksi Promosi Jabatan Karyawan Dengan Algoritma C4.5 (Studi Kasus: Apartemen Senayan Jakarta). TechnoCom. 2019;18(4):288-98. 